\title{
Erratum to: The glucose-induced synthesis of insulin in liver
}

\author{
Rajeshwary Ghosh · Soumendra K. Karmohapatra • \\ Gorachand Bhattacharya $\cdot$ A. Kumar Sinha
}

Published online: 7 December 2011

(C) Springer Science+Business Media, LLC 2011

\section{Erratum to: Endocrine (2010) 38:294-302}

DOI 10.1007/s12020-010-9388-3

On page 295, in the Results section under "The staining of protein bands from different cell suspension incubated with glucose in the SDS-polyacrylamide gels after electrophoresis by Coomassie blue and by immunoblot technique using anti insulin antibody," the optimal glucose concentration must be $0.02 \mathrm{M}$ and not $0.2 \mathrm{M}$.

On page 297, "blood sugar level in the alloxan treated diabetic mice that weighs $600 \mathrm{mg} / \mathrm{ml}$ before the injection of supernatant lowered to $350 \mathrm{mg} / \mathrm{dl}$ " should read "blood sugar level in the alloxan treated diabetic mice that was $600 \mathrm{mg} / \mathrm{dl}$ before the injection of supernatant lowered to $350 \mathrm{mg} / \mathrm{dl}$."

On page 300, in the Materials and Methods section, "Preparation of hepatocytes from the mice pancreas" should read "Preparation of hepatocytes from the mice liver."

On page 301, at the start of the second paragraph under "Bioassay of insulin using diabetic mice," "five equal groups" should read "two equal groups."

The online version of the original article can be found under doi:10.1007/s12020-010-9388-3.

R. Ghosh · S. K. Karmohapatra · A. Kumar Sinha ( $₫)$ Sinha Institute of Medical Science and Technology, 288, Kendua, Main Road, Garia, Calcutta 700 084, India e-mail: asruksinha@yahoo.com

G. Bhattacharya

Calcutta National Medical College and Hospital, Calcutta

700014, India 